\title{
Implicațiile propagandei în reflectarea și redefinirea realităţii
}

\author{
DOI : $10.46522 / \mathrm{S} .2021 .02 .03$
}

\author{
Adriana BOANTĂ PhD \\ University of Arts, Târgu Mureș \\ adriana.artdesign@gmail.com
}

\begin{abstract}
The Implications of Propaganda in Reflecting and Redefining Reality Today technology touches nearly every aspect of our lives, affecting profoundly our activities and reshaping the information environment. The new digital era provides innumerable opportunities to create connections and share ideas and information and even build a new reality. The high-speed Internet has expanded circle of social connections and increased communication opportunities for the social, economic and cultural sectors as well as enhancing efficient access to information and cultural resources. Unfortunately, though, the same technologies can also serve to pollute our online „ecosystem”. They can be used to manipulate at a scale that was never possible. In this information-oversaturated world, fake news and propaganda have taken many forms and simultaneously contribute to undermine, reshape and redefine reality. Our study aims to reveal the way in which reality is redefined and reshaped in this communication context.
\end{abstract}

Key words: fake news, propaganda, post-truth, manipulation, social media.

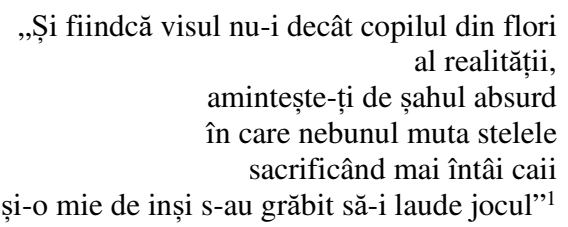

(Dinescu, 1979, p.13)

Tehnologia influențează aproape toate aspectele vieții noastre, afectându-ne profund activitatea, (re)modelând continuu mediul informațional. Noua eră digitală oferă nenumărate oportunități pentru a crea noi conexiuni și pentru a transmite idei și informații într-un mod extrem de rapid, și, mai mult decât atât, contribuie la edificarea

\footnotetext{
${ }^{1}$ Mircea Dinescu, Șah absurd, versuri excluse de cenzură în perioada comunistă.
} 
unei noi realităţi, ce se folosește atât de coordonatele fizice ale imediatului, cât și de atributele mediului digital. Puse împreună, cele două dimensiuni (fizică și virtuală), transformă procesul perceptiv și de comunicare într-o experiență unică. Totodată, Internetul de mare viteză a extins posibilitățile de comunicare în mediul social, a modelat și (re)definit arealul în care ne manifestăm și activăm, fie că e vorba de mediul economic, educațional și artistic, facilitând accesul la informații și resurse culturale diverse (baze de date, arhive digitalizate, muzee virtuale etc.). Dar, în egală măsură, aceleași tehnologii pot servi și la poluarea „ecosistemului” nostru on și off-line. Dezvoltarea noilor tehnologii de comunicare a schimbat radical modul în care informația este gestionată, filtrată, înțeleasă, manipulată, odată ce a fost transferată din mediul concret, fizic, în cel digital și viceversa.

Ca urmare a digitalizării masive, practica jurnalistică devine rezultatul unei acțiuni colaborative și participative, de tip rețea, care se bazează pe aportul contributiv al mai multor actanți, dornici să creeze și să publice conținut. Democratizarea mediului onli$n e$, în sensul accesibilizării, a adus laolaltă, în aceeași mare redacție a online-ului jurnaliști instruiți, dar și „,profani” în ale meseriei; impostori și manipulatori media, oameni simpli, „troli clasici” și „troli hibrizi” (Spruds, 2016, p.10). Toți participă activ la schimbul de informații și își arogă dreptul legitim de a servi interesul public, chiar dacă nu sunt întotdeauna familiarizați cu rigoarea practicii jurnalistice și cu principiile etice și deontologice. Tocmai de aceea anumite elemente structurale esențiale jurnalismului, precum calitatea informației, redarea adevărului faptic, acuratețea surselor citate, calitatea mesajului, elementele de retorică, modalitatea de prezentare și de adecvare a mesajului la context, tind să devină preocupări de rang secund, atunci când scopul prim al creatorului de conținut media este doar imediatețea, audiența de masă (potențialul viral) și interesul pecuniar. Russel Frank leagă acest proces de deprofesionalizare a a domeniului jurnalistic de apariția mediilor alternative și a fenomenului fake news, definit ca o poveste generată într-un context social neprofesionist, care folosește stilul de ştire, fie pentru a parodia acel stil, pentru a satiriza problemele și personalitățile din știre (Frank, 2015, p.316).

Vorbind despre comunicare, sociologul Philippe Breton consideră că cei trei piloni care stau la baza interacțiunilor sociale între indivizi sunt informarea, convingerea și exprimarea. În sens larg, a fi informat despre ceva înseamnă să deții în amănunt detalii factuale concrete, corecte și complete despre un subiect, chiar dacă fiecare dintre noi filtrează, decupează și conotează diferit informația, construind sensuri și lărgind rețeaua de semnificații. Independent de valorile teoretice fundamentale ale informației - validitatea, precizia, consistenţa, completitudinea şi utilitatea - principiile care stau la baza comunicării, procesul de comunicare se bazează pe pluralitatea criteriilor valorice de selecție, diferenţiate în funcție de mediu, dar și de miza celui care „controlează” informația prin procesul de selecție și de difuzare. Fenomenul se acutizează în situațiile de criză sau în ,,societățile închise”, când constrângerile politice și cele date de problemele stringente ale momentului, incertitudinea, lipsa de predictibilitate, de încredere și de 
securitate influențează practicile de observare, interpretare, verificare și validare a informației, și implicit, alterează procesul de comunicare.

Folosirea în exces a tehnologiei ne-a făcut pe toți vulnerabili la distorsiuni și dezinformări, și a dezvoltat o serie de concepte de la yellow jurnalism la fake news și deep fake, shilling, până la botnet-uri, troll farms și metaverse. Astăzi, mai mult decât oricând, mediile pot fi și, de altfel, sunt folosite pentru a manipula la o scară la care nu a fost posibilă niciodată până acum, deși influențe și practici maligne ${ }^{2}$ ale modului de utilizare și de diseminare a informației au fost folosite cu mii de ani înaintea așa-numitei erei pre-smartphone sau a celei ,post-adevăr". ${ }^{3}$

Chiar dacă au existat dintotdeauna mincinoşi, minciunile erau spuse, de regulă, cu un pic de neliniște, un pic de vinovăție, puțină rușine [...] Acum, fiind oameni inteligenți, am inventat motive raționale pentru manipularea adevărului, astfel încât să putem să ne simțim nevinovați. Numesc asta post-adevăr.

Keyes, 2004, 12

Totuşi, reflectarea parțială, fragmentară, decontextualizată, voit sau neintenționat eronată a informației (misreporting) nu are drept miză doar decredibilizarea, influențarea maselor sau diversiunea, prin distragerea atenției de la adevărul faptic, aşa cum s-ar putea crede la o primă ,lectură”, ci impunerea unei noi realităţi, a unui nou reper, dar și statuarea unei noi mitologii. Astfel, în acest nou context suprasaturat de informații vizuale și scrise, știrile false și propaganda contribuie simultan la (re)modelarea și, totodată, (re)definirea realităţii, fie că este vorba de reflectarea prezentului imediat, a informației brute, pe care o subminează, prin impunerea unor grile de reprezentare, fie că este vorba de realitatea manipulată (editată, construită, prefabricată), redată parțial sau în mod voit distorsionat, așa cum întâlnim deseori în mediul online, în special pe rețelele de socializare, dar nu numai.

2 În definițiile formulate de dicționare, noțiunea ,,propagandă”, are la bază latinescul papagare, cu înțelesul de a ,promova”, ,răspândi”, ,,crește”, ,dezvolta” idei, principii, doctrine, având scopul de a influența și transforma opinii, mentalități, comportamente, destine individuale și colective.

${ }^{3}$ Termenul post-truth îi aparține scriitorului și scenaristului Steve Tesich, care îl enunță în eseul The Watergate Syndrome: A Government of Lies, publicat în The Nation (1992). Ralph Keyes este cel care preia și dezvoltă termenul în lucrarea The Post-Truth Era: Dishonesty and Deception in Contemporary Life (2004), iar mai apoi, în 2012 a fost repus în circulație de profesorul și politologul Inderjeet Parmar, cu referire la contextul politic generat de alegerile din Statele Unite, pentru a descrie starea de fapt care domina discursul public, în care recursul la fapte și argumente nu mai conta în procesul de înțelegere și diseminare a informației, și implicit, de reflectarea a realității. Acest lucru permite coexistența a mai multor realităti, în care faptele sunt construite, manipulate în funcție de ideologii, convingeri sau prejudecăți. Cu toate acestea nu se dorește impunerea unei metarealități sau a unei realități alternative, scopul este mult mai simplu: subminarea încrederii în realitatea (politică, socială) existent sau deturnarea atenției prin introducerea în spațiul public, în mod sistematic a informațiilor false. 
În societățile totalitariste, controlate ideologic, responsabilitatea individuală în procesul de luare a deciziilor este eludată sau transferată unor terți. Astfel, deciziile personale sunt luate potrivit unor „credințe” și informații impuse de ,grupul” dominant, alteori doar de o grupare, cu scopul deliberat de a obține controlul asupra maselor (v. Popper, 1993). În consecință, atât realitatea reflectată, cât și mesajul, codul de comunicare, canalul de transmitere și receptorul informației devin vulnerabile, deoarece depind de „buna credință” a emitentului, în funcţie de care se stabilește calitatea și valoarea procesului de comunicare. Orice încercare deliberată de a influența opinii este, potrivit lui Robert Cirino, parte din mecanismul propagandei sau din ceea ce politologul American Harold D. Lasswell numea managementul mijloacelor de comunicare în scopuri politice (Lasswell, 1951, 214). În Ușor de condus. O istorie a propagandei, Oliver Thomson definește propaganda ca ,utilizarea de către un grup de oameni a capacităților de comunicare de orice fel cu scopul modificării atitudinii sau comportamentului altui grup" (Thomson, 1999, 5).

Fenomen complex, persuasiv și pervaziv, propaganda este un instrument de răspândire a ideologiei, de configurare şi (re)configurare a informației și realitătii. Prin mijloacele și metodele folosite, prin structurile organizatorice pe care le angrenează, dar și prin forța de impact a mesajului, propaganda are menirea de a convinge ,prin instigare ce tinde să înlocuiască rațiunea cu iresponsabilitatea, ștergând linia de demarcație dintre adevăr și fals” (apud. Denize, 2011, 21). De altfel, diferența de fond dintre informare și propagandă rezidă în scopul exprimat, și impactul generat. În timp ce propaganda urmărește ,înrobirea indivizilor, informația vizează eliberarea acestora (...) mijloacele brutale de propagandă sunt mai eficiente decât informarea imparțială. Este mai ușor și exercită o mai mare tentație să înrobești oamenii decât să-i eliberezi" (apud. Włodzimierz și Miszewski, 1979, 66). În acest context, imaginea este transformată în , instrument de manipulare și de control", deoarece actorii socio-politici au nevoie să ișși legitimeze acțiunile și se „dotează cu un adevăr, și mai ales cu o putere de impunere” (Wunenburger, 2005, 61).

În perioada experimentelor politice totalitariste naziste și comuniste, în demersul de convertire a maselor şi de impunere a fantasmelor ideologice, regimul opresiv a creat prin mecanismul propagandei, o suprastructură de control, dar și o realitate distopică a cărui imaginar a statuat un nou canon de reprezentare sau o contra realitate.

Ceea ce deosebeşte comunismul de alte experienţe totalitare, şi mai ales de filozofiile fasciste ale acţiunii pure este cu siguranţă punctul său de sprijin ştiinţific, referinţele şi obsesiile sale livreşti. Toţi şefii comunişti au scris enorm (sau cel puţin s-au prefăcut că o fac), toţi au fost foarte preocupaţi de problemele teoretice [...] A fost o civilizaţie a scrisului, scris vrând să însemne în acest caz Scriptură, o colecţie de texte sacre, copiate şi recopiate, compilate, interpretate la nesfârşit.

Boia, 2011, 89

Potrivit lui Emilio Gentile, ambele ideologii au fost ,,[...] forme de sacralizare a politicului, cu o trăsătură unică şi integralistă ce respingea «coexistența cu alte ideologii şi 
mişcări politice», nega «autonomia individului cu privire la grup», prescria «respectarea obligatorie a preceptelor [lor] şi participarea la cultul [lor] politic» şi consfinţea «violenţa ca armă legitimă a luptei împotriva duşmanilor şi instrument de regenerare»." (apud. Tismăneanu, 2013, 17)

Arta vizuală (pictura, fotografia, filmul, în special arta grafică) este una dintre cele mai eficiente forme de influențare, manipulare și control al maselor, prin impactul puternic și direct pe care imaginea atent aleasă, dublată de un mesaj antrenant, activ (agitator și/sau militant) poate modela percepții, devenind un instrument-cheie al propagandei. Datorită mijloacelor pe care le folosește (satira, hiperbolizarea, contrastul), arta grafică (afiș, caricatură) a fost folosită ca instrument agitatoric al propagandei, pentru a satisface nevoile de schimbare ale societății. Astfel, arta grafică a fost folosită atât ca armă împotriva unor ideologii, persoane, cât și ca mijloc de control și persuadare, de inoculare a unor noi idei și formarea de stereotipuri ${ }^{4}$.

Dar propaganda nu are doar rolul de a răspândi o opinie sau idei doctrinare, pentru a le face cunoscute, iar mai apoi acceptate de către mase, ci şi acela de a seduce şi modela conștiințe apelând nu numai la fapte, ci și la aspectele emoționale. (Tămaș, 1997, p.219). În toate regimurile totalitare, propaganda utilizează în procesul de comunicare, o strategie persuasivă care speculează din plin factorul emoțional. În procesul de ,,educare" ideologică și de transmitere a mesajului dorit, propaganda folosește un limbaj simplu, convingător, adeseori cu formulări sterile, clișeistice, dar care abundă în formulări elogioase la adresa regimului. Excesiv și abraziv, deopotrivă, mesajul propagandei face apel la o serie de prejudecăți și stereotipii de gândire și de reprezentare, care alimentează revolta născută din frustrări și neajunsuri. Temele dezvoltate în cadrul discursului propagandistic în perioada comunistă erau, pe de-o parte, cele care incitau la violență și la „lupta de clasă”, iar pe de altă parte, elogioase la adresa regimului și a exponenților săi.

În acest proces de (re)definire a realității un rol important 1-au avut și instituţiile de cultură și presa (scrisă şi audio-vizuală), care au fost transformate în agenți activi ai propagandei, având rolul de a transmite maselor - mesajul ideologic. Iar dacă ideile (ideologice s.m.) au venit de la politicienii care au luat în serios politica de putere, tehnicile au venit de la oamenii simpli care nu se fereau să fie în concordanţă, după cum remarca Hannah Arendt în Essays in Understanding, 1930-1954: Formation, Exile, and Totalitarianism (Arendt, 1994, 205).

Scriitori, artiști și jurnaliști, ca „exponenți ai opiniei publice” au fost chemați să facă din artă și din presă o tribună demnă de ,înălțimea” și „,măreția” Epocii. Mulţi şi-au

${ }^{4}$ Artiștii propagandei ruse care au creat un canon de reprezentare adoptat în toate țările comuniste, au fost formați la institutul de arte Vkhutemas sau „Bauhaus-ul sovietic”: Gustav Klutsis, Kukryniksky, Irakly Toidze, Aleksiej Kokorekin, Viktor Koretsky, Dementy Shmarinov, Pavel Sokolov-Skalya, Dimitri Moor etc. În spațiul american, propaganda vizuală dispunea de serviciile lui Herbert Bayer, iar în Marea Britanie de echipa coordonată de Milner Gray. 
asumat misiunea propagandistică și au contribuit voluntar la procesul de dislocare a „falsei conștiințe” a celor cu „origini nesănătoase” și la edificarea unor atitudini politice și civice „,corecte”, care aveau la bază principiile „echităţii socialiste”. În acest sens, criticul de artă Mircea Popescu remarca în articolul

Certitudini și perspective în pictura românească actuală, apărut în 1960 în revista Arta plastică: ,,arta are menirea de a contribui la accelerarea procesului de formare a conștiinței socialiste [...] subiectele operelor de artă nu pot fi desprinse decât din acele sectoare ale realității noastre, în care conștiința socialist se afirmă cel mai puternic.

Popescu, 1960, 5

În realitate, punerea activității de creație exclusiv în slujba poporului s-a dovedit a fi un eșec. Astfel, arta pentru popor devine inevitabil, arta de propagandă, remarca Jacques Maritain în The Responsability of the Artist (1960).

Pentru eficientizarea transmiterii mesajului propagandistic, se urmărea impactarea cititorului, fără ca acesta să aibă sentimentul că este manipulat. Astfel, potrivit publicației „Presa noastră”, jurnalistul trebuia să surprindă imaginea unei realități „,conforme” - care să se ridice la nivelul cerințelor ,societății multilateral dezvoltate” (creionată după chipul și asemănarea „ilustrului”) - gata oricând să primească viza „bun de tipar” sau „bun de difuzat” din partea Direcției Generale a Presei și Tipăriturilor, dar și să ofere senzația că informațiile transmise sunt noi, relevante și capabile să trezească conștiințele, chiar dacă au fost redate sub o altă formă în materiale de presă publicate și difuzate anterior. Sub pretextul apărării secretului de stat și preîntâmpinării tipăririi și diseminării de materiale cu caracter „dușmănos” și potențial subversiv, care să aducă atingere „valorilor” regimului s-au creat o serie de mecanisme de cenzură. Acestea funcționau ca filtre de supraveghere și control, având la baza criteriilor de selecție, reglementările enunțate în documentul Instrucțiuni pentru cenzura presei și a tipăriturilor, iar mai apoi, prevederile aşa-numitului „Caiet de dispoziții” - codexul cenzurii comuniste în România - introdus ca instrument de lucru în 1963. (Erhan, apud. E. Șercan, 2015, pp.98-99). „Ideologiile sunt asemeni genelor care controlează culturile și societățile. Ele constituie planuri după care sunt construite realităţile" (Chirot, 1996, 191).

O posibilă explicaţie a lașității, resemnării este surprinsă de Hannah Arendt:

Lipsa de rezistenţă, abandonarea în faţa acestui proces brutal de dezintegrare a devenit o ispită căreia, s-ar părea, nu i se mai poate rezista, nu numai din cauză că procesul de care e vorba şi-a asumat proporţiile măreţiei mincinoase a «necesităţii istorice», ci, de asemenea, pentru că tot ceea ce nu mai aparţine acestei evoluţii a început să apară lipsit de viaţă, secătuit de sânge, fără niciun înţeles şi ireal.

Arendt, 1994, 8 
Tot acest construct fals, butaforic, creat cu scopul de a impresiona și, totodată, de a înșela opinia publică, prin proiecția unei realități de tip Potemkin ${ }^{5}$, în care fațada adevărului era zugrăvită în culori stridente, a fost susținut de instituții și de un aparat de propagandă supradimensionat, a căror misiune era de a construi și întreține iluzia, clădită din narațiuni false, și de a-i amplifica efectul. Mesajul propagandistic era promovat prin imagini și titluri de impact, într-un limbaj accesibil maselor, în care au fost inserate simboluri și cuvinte-cheie, pline de semnificații, menite să genereze o reacție imediată.

O diferență fundamentală între dictaturile moderne și toate celelalte tiranii ale trecutului o constituie faptul că teroarea nu mai este folosită ca mijloc de exterminare și intimidare a oponenților, ci ca un instrument de a guverna masele populare, care sunt cu totul şi cu totul ascultătoare.

Arendt, 1994, 19

Şi în spaţiul online, regăsim numeroase narațiuni false. Întreg fenomenul fake news se bazează pe transmiterea de informații lipsite de fundament, pe dovezi fabricate, pe conținuturi denaturate, analogii forțate, speculații și mesaje senzaționaliste, tendențioase care nu au la bază un adevăr faptic, științific și care au capacitatea de crea o falsă realitate. Fake news-ul își fundamentează mesajul aducând în prim-plan declarații, mărturii, pseudo-adevăruri (deoarece operează cu jumătăți de adevăr), care amestecă informații factuale cu cele fictive sau (re)utilizează conținutul, inserându-l într-un alt context, cu scopul programat, intenționat, deliberat, de a induce în eroare a publicului, controlându-1.

Știrile care au cel mai mare potențial de viralizare se răspândesc în mediul online, prin intermediul rețelelor de socializare, care eludează orice normă și conduită profesio-

${ }^{5}$ Grigori Potiomkin sau Potemkin, ministrul și guvernatorul Crimeii a rămas în istorie şi datorită campaniei organizate în anul 1787, prilej pentru împărăteasa Ecaterina a II-a a Rusiei să viziteze noile teritorii din Crimeea, proaspăt anexată Imperiul Țarist. Vizita imperială a durat șase luni, iar amploarea acestui eveniment a presupus un efort organizatoric important, implicând un număr impresionat de participanţi, diplomaţi agenţi de influență şi capete încoronate (Iosif al IIlea, Prințul de Ligne). Miza uriașei mobilizări a fost stabilirea de noi alianțe în perspectiva a ceea ce se anunța a fi al doilea război ruso-turc. În acest scop s-a urmărit seducerea delegaţilor străine şi convingerea lor că Imperiul Rus are resurse materiale şi militare importante, dovada fiind „prosperitate” Crimeii. Mizând pe propagarea ulterioară a acestei informații abil construite, Potemkin reușește în cinci ani să construiască imaginea unei Crimei demnă de măreția imperiului și de gloria Ecaterinei. Plantează păduri, construiește uzine, drumuri, fortificații, chiar și un oraș, Ecaterinoslav (astăzi Dnipro). Ecaterina și invitații ei sunt îmbarcați pe nave somptuoase, care navighează pe Nipru, de la bordul cărora contemplă spectacolul regizat de Potemkin: case idilice, turme care pasc, țărani care cântă şi dansează. După ce navele trec, decorul se strânge, figuranții formați din țărani iobagi sunt urcați în căruțe și mutați în următorul loc, unde va avea o nouă reprezentație. Jurnalistul Gustav Adolf Wilhelm von Helbig, parte din delegația germană avea să numească satele înșirate de-a lungul râului Nipru, „Potemkinsche Dörfer” sau ,,satele lui Potemkin”, aceasta expresie a rămânând în limba germană, cu sensul de cacealma, înșelător. 
nală legată de practica și etica jurnalistică pentru un succes imediat, facilitat de clickbait, iar astfel de a beneficia de capital de imagine, economic, politic etc. Acestor informații li se dă o aura de credibilitate prin citarea unor surse aparent valide, prin inserarea în discursul jurnalistic a unor declarații atribuite unor așa-ziși „specialiști” sau „,cercetători de renume” din centre de cercetare de prestigiu. Însă, de cele mai multe ori, legătura dintre aceste persoane și instituțiile asociate lor, este fie tangențială, fie prezentată într-un mod voit eronat, fie este un construct pur ficțional. Mai mult decât atât, ca să-și legitimizeze și credibilizeze intenția, fake-news-ul împrumută din arsenalul de mijloacele și de instrumente de comunicare proprii jurnalismului tradițional, însă toate strategiile, metodele sunt folosite în mod parazitar și abuziv pentru a transmite informația într-o formă alterată, recontextualizată.

Astfel, informației i se conferă un alt sens și o altă utilitate și, desigur capătă o altă importanță. „Unul dintre cele mai îngrozitoare aspecte ale terorii contemporane este acela că, indiferent de motivaţiile şi scopurile ei supreme, apare invariabil în straiele unei concluzii logice ineluctabile, derivată dintr-o ideologie sau teorie" (Arendt, apud.Tismăneanu, 2013, 262).

Strategia de comunicare se bazează și pe fake news: emoție generată de sensationalism, exagerări grosiere, violența limbajului, impactul mesajului (sloganul) și al imaginii (supradimensionate, colate, editate) și pe o imediatețe aproape instantanee, grefate pe realitatea ale cărei valori și granițe se volatilizează, și se transformă într-o structură în care coexistă vidul moral, ignoranță, autosuficiență, inflația de informații și comunicatori reali sau fictivi (bloggers, vloggers, influencers, sockpuppets, trolls) conduc la o supralicitare a simulacrelor.

Mecanismul persuasiv de producere și „post producție” a știrilor false se bazează pe procedee simple: imagini și titluri de impact, scrise într-un mod atractiv sau disproporționate în raport cu evenimentul reflectat sau pur și simplu fabricate (deepfakes), cu scopul de a seduce, destabiliza, deci de a influența opinia publică în direcția dorită; inserarea de elemente inedite, surprinzătoare, care generează emoții puternice (negativepozitive, apreciere-respingere, bucurie-furie), care asigură implicarea publicului și diseminarea voluntară, pe scară largă a informației; crearea unei false aure de autenticitate și credibilitate prin insearea de dovezi, studii ale experților menite să construiască încrederea (woozle). Potrivit lui James Pamment, atunci când anumite narațiuni au la bază afirmații, fapte care nu pot fi susținute cu dovezi, dar sunt invocate și citate frecvent, în cele din urmă vor fi receptate și validate de public ca adevărate. (Pammnet et al., 2018, p.53) În cadrul studiului Hoaxy: A Platform for Tracking Online Misinformation, Shao Chencheng, împreună cu colaboratorii săi Giovanni Luca Ciampaglia, Alessandro Flammini, Filippo Menczer demonstrează magnitudinea fenomenului, susținând că diseminarea știrilor false este o activitate întreținută și dominată de un număr restrâns de comunicatori, de câteva conturi foarte active, în timp ce propagarea verificării informației este o activitate mult mai răspândită, specifică publicului larg. 
Publicațiile online și site-uri care își construiesc conținutul editorial pornind de la fake news publică în mod constant articole considerate pseudoștiințifice sau materiale (vizuale și scriptice) asociate teoriilor conspiraționiste. Armele pe care aceștia le folosesc pentru a-și construi credibilitatea, și pentru a oferi greutate celor expuse sunt împrumutate din lexicul jurnalistic. Întâlnim în discursul lor sintagme precum „surse care doresc să-și păstreze anonimatul” sau ,,pe surse”, sintagme pe care le folosesc în mod abuziv, tocmai pentru că înțeleg valoarea și forța pe care le dețin în interiorul breslei unor astfel de coduri de comunicare. Ele folosesc dreptul sacrosanct al jurnaliștilor, acela al libertății de expresie și de a nu-și dezvălui sursele pentru a „,proteja” minciuna, impostura.

Astfel, ne aflăm astfel într-un proces de confiscare, subminare, decredibilizare și implicit, desacralizare a domeniului jurnalistic. Desacralizarea prin practicile de manipulare a informației se accentuează și acutizează în perioadele de criză, când dezinformarea la comandă este mult mai prezentă și este transformată în armă. Asemenea practici orchestrate de aparatul propagandistic vizează subminarea încrederii în autorități şi mijloacele de informare tradiționale. Teoriile conspiraţioniste își intensifică prezența în timpul conflictelor sau în perioadele de schimbare a regimurilor politice, fiind activate și înteținute prin intermediul campaniilor de dezinformare desfășurate în toate mediile sociale, pe toate platformele de comunicare ale principalilor actori din peisajul mediatic.

Deși potrivit News Guard Tech și Media Bias Fact Check, două organizații care evaluează gradul de acuratețe a informațiilor publicate în spaţiul online, platformele care publică cu predilecție informații false au un grad scăzut de credibilitate. Federaţia Europeană a Jurnaliştilor (EFJ), Asociaţia Europeană a Editorilor (FEP) şi Uniunea Posturilor TV Private consideră că sunt necesare măsuri suplimentare, mult mai ferme pentru platformele care permit prin intermediul serviciilor oferite, diseminarea de informații care nu respectă ,regulile jocului”.

$\mathrm{Cu}$ toate acestea, este nevoie de discernământ în modul în care se stabilește și se defineşte o informație ca fiind fake news, față de o opinie exprimată mai contondent sau mai plastic. Avem nevoie de aceasta atitudine critică, lucidă asupra analizei conţinutului unei informații, ca să nu cădem în cealaltă extremă și să lezăm, ceea ce de facto cultivăm și apărăm: libertatea de exprimare.

\section{REFERINȚE}

ARENDT, Hannah, 1994. Essays in Understanding, 1930-1954: Formation, Exile, and Totalitarianism, New York: Kern, Harcourt, Brace, Jovanovich;

ARENDT, Hannah, 1994. Originile Totalitarismului, ediția a III-a, trad.:Ion Dur și Mircea Ivănescu, București: Humanitas;

BESANÇON, Alain, 2015. Nenorocirea secolului. Despre comunism, nazism şi unicitatea ,Soah"-ului, trad.: Mona Antohi, București: Humanitas; 
BOIA, Lucian, 2011. Mitologia științifică a comunismului, ediția a 3-a, traducere din franceză de autor, București: Humanitas;

BRUNEL, Pierre (coord.), MANCIER, Frédéric și LETOURNEUX, Matthieu, 2003. Miturile secolului $X X$, vol. 2, trad.: Sanda Oprescu, București: Univers;

CHENCHENG, Shao și Ciampaglia et al. Flammini, Menczer, 2016. Hoaxy: A Platform for Tracking Online Misinformation. Disponibil la https://www.researchgate.net/publication/301841797_Hoaxy_A_Platform_for_T racking_Online_Misinformation, la data 18.04.2021;

CHIROT, Daniel, 1996. Societăți în schimbare, trad.: Daniela Tabac, București: Athena;

CIRINO, Robert, 1971. Don't Blame the People: How the News Media Use Bias, Distortion and Censorship to Manipulate Public Opinion, New York: Vintage Brook a Devision of Ramdom House;

DENIZE, Eugen, 2011. Propaganda comunistă în România (1948-1953), Târgoviște: Cetatea de Scaun;

DINESCU, Mircea, 1979. La Dispoziția Dumneavoastră, București: Cartea Românească;

ERHAN, Ioan, 1984. Partinitatea o trăsătură definitorie a presei noastre comuniste, în Presa noastră, nr.5 (mai) publicată de Uniunea Ziaristilor din R.S.România, Disponibil la: http://restitutio.bcub.ro/handle/123456789/521 (pp.224-225), la data de : 17.10.2021;

FRANK, Russell, 2015. Caveat Lector: Fake news as Folklore, în The Journal of American Folklore Vol. 128, No. 509, University of Illinois Press. Diponibil pe https://www.researchgate.net/publication/281601869_Caveat_Lector_Fake_New S_as_Folklore, la data de 19.10.2021

KEYES, Ralph, 2004. The Post-Truth Era: Dishonesty and Deception in Contemporary Life, New York: St. Martin's Press;

KNOBELSDORF, Włodzimierz și MISZEWSKI, Bronisław, 1979. Caiet Documentar, 7/1979, București;

MANCIER, Frédéric şi LETOURNEUX, Matthieu, 2003. Miturile secolului XX, vol. 2, trad.: Sanda Oprescu. București: Univers;

MARITAIN, Jacques, 1960. The Responsability of the Artist, Capitolul 3, Art for the People, Disponibil pe: https://maritain.nd.edu/jmc/etext/resart.htm, la data de 10.04.2021;

OPREA, Bogdan, 2021. Fake news și dezinformare online: Recunoaște și verificăă, Iași: Polirom;

PAMMENT, James și NOTHHAFT, Howard și Agardh-Twetman, Henrik, Fjällhed, Alicia, 2018. Countering Information Influence Activities: The State of the Art, version $1.4 . \quad$ Disponibil pe: https://portal.research.lu.se/en/publications/countering-information-influenceactivities-the-state-of-the-art, la data de 20.04.2021; 
POPESCU, Mircea, 1960. Certitudini și perspective în pictura românească actuală, în revista Arta plastică, nr.4;

POPPER, Karl R.,1993. Societatea deschisă și dușmanii ei, vol.2, București: Humanitas;

ROUQUETTE, Michel-Louis, 2002. Despre cunoașterea maselor. Eseu de psihologie politică, trad.: Raluca Popescu și Radu Gârmacea, Iași: Polirom;

ŞERCAN, Emilia, 2015. Cultul secretului, prefață Mihai Coman, Iași: Polirom;

TĂMAȘ, Sergiu, 1997. Dicționar politic: Instituțiile democrației și cultura civică. București: Editura Academiei Române;

TESICH, Steve, 1992 (6 ianuarie). The Watergate Syndrome: A Government of Lies, în The Nation Disponibil la https://www.thenation.com/article/archive/post-truthand-its-consequences-what-a-25-year-old-essay-tells-us-about-the-currentmoment/, la data de 17.10.2021;

THOMSON, Oliver, 1999. Easily Led. A History of Propaganda, Londra: Sutton Publishing;

TISMĂNEANU, Vladimir, 2013. Diavolul în istorie. Comunism, fascism și câteva lecții ale secolului $X X$, traducerea din engleză de Marius Stan, București: Humanitas;

WUNENBURGER, Jean-Jacques, 2005. Imaginariile politicului, trad.: lonel Buşe și Laurenţiu Ciontescu-Samfireag, Bucureşti: Paideia. 